\title{
Financial Capacities and export success: Evidence from Small and Medium-Sized Estonian Firms
}

\section{Capacidades financieras y éxito de las exportaciones: Evidencia de Pequeñas y Medianas Empresas Estonias}

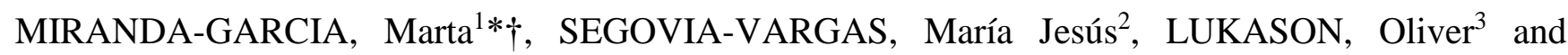 \\ VISSAK, Tiia $^{4}$ \\ ${ }^{1}$ School of Economics and Business Administration, Rey Juan Carlos University, Calle Tulipán, s/n, 28933 Móstoles, Madrid, \\ Spain
}

${ }^{2}$ School of Economics and Business Administration, Complutense University of Madrid. Av. Séneca, 2, 28040 Madrid, Spain.

${ }^{3,4}$ School of Economics and Business Administration, University of Tartu Ülikooli 18, 50090 Tartu, Estonia

ID $1^{\text {st }}$ Author: Marta, Miranda-Garcia / ORC ID: 0000-0001-9731-496X

ID $1^{\text {st }}$ Coauthor: María Jesús, Segovia-Vargas / ORC ID: 0000-0002-6578-8017, Researcher ID Thomson: I-3637-2017

ID $2^{\text {nd }}$ Coathor: Oliver, Lukason / ORC ID: 0000-0001-8135-1010, Researcher ID Thomson: G-9704-2019

ID $3^{\text {rd }}$ Coauthor: Tiia, Vissak / ORC ID: 0000-0002-4984-3629, Researcher ID Thomson: C-8580-2011

Received: March 20, 2019; Accepted: May 20, 2019

\section{Abstract}

The main objective of this paper is to investigate the relationships between exporting success and variables that affect the economic and financial structure. For a set of 242 Small and Medium-Sized Estonian firms, we will analyze how financial variables contribute to the achievement of higher export success rates. We select the relevant variables with Principal Component Analysis and use an Artificial Intelligence method (PART algorithm) to study the role of them. The results show that the more relevant financial variables to analyze the success in international market are the ones related to the liquidity of the assets, the level of interest payments, sales growth, the ones related to firms' own funds and the age of the company. In addition, although some financial factors are more significant than others, none of them is clearly a key factor for all companies and situations, that is, no single factor can lead to success or failure.

Financial capacities, Export success, Artificial intelligence, PART algorithm, Principal component analysis

\begin{abstract}
Resumen
El objetivo principal de este documento es investigar las relaciones entre el éxito de la exportación y las variables que afectan la estructura económica y financiera. Para un conjunto de 242 empresas estonias pequeñas y medianas, analizaremos cómo las variables financieras contribuyen al logro de mayores tasas de éxito en las exportaciones. Seleccionamos las variables relevantes con el Análisis de componentes principales y utilizamos un método de inteligencia artificial (algoritmo PART) para estudiar el papel de las mismas. Los resultados muestran que las variables financieras más relevantes para analizar el éxito en el mercado internacional son las relacionadas con la liquidez de los activos, el nivel de pagos de intereses, el crecimiento de las ventas, las relacionadas con los fondos propios de las empresas y la edad de la empresa. . Además, aunque algunos factores financieros son más significativos que otros, ninguno de ellos es claramente un factor clave para todas las empresas y situaciones, es decir, ningún factor puede llevar al éxito o al fracaso.
\end{abstract}

Capacidades financieras, Éxito de exportación, Inteligencia artificial, algoritmo PART, Análisis de componentes principals

Citation: MIRANDA-GARCIA, Marta, SEGOVIA-VARGAS, María Jesús, LUKASON, Oliver and VISSAK, Tiia. Financial Capacities and export success: Evidence from Small and Medium-Sized Estonian Firms. ECORFAN JournalMexico. 2019, 10-22: 39-54.

\footnotetext{
* Correspondence to Author (marta.miranda@urjc.es)

$\dagger$ Researcher contributing first Author.
} 


\section{Introduction}

This work has a threefold objective. The first is to analyze the direct relationship that may exist between economic-financial variables and the investment decisions implicit in the continuous presence in international markets. The relationship between investment decisions and financial variables has been extensively studied, using the concept of financial restriction as a moderating or an intermediate variable.

\section{Economic-financial variables $\longrightarrow$ Financial} restriction $\longrightarrow$ Investment decisions

However, given the proposed methodology, the variables used in the model will be those that, according to the most recent and relevant literature, may be the cause of the appearance of financial restrictions, which would be an obstacle to making investments in general and, in particular, those necessary to carry out an international activity.

It is evident that the companies that present greater restrictions will have more difficulty to invest, either in national or international markets. However, given the little consensus that exists in how these restrictions are generated and therefore which variables influence their appearance, this paper tries to discover patterns of behavior directly of the financial economic variables without using the financial restrictions as a moderating variable.

Firms' export performance depends on many different factors (Harris and Li, 2011). Overall, exporter performance reflects the result from a specific firm's exporting behavior under specific environmental circumstances (LandaTorres, et al. 2012). It is possible to identify three dimensions of the exporting behaviour: economic, financial, and strategic (Katsikeas et al. 2000).

In general, firms' heterogeneous resources are considered as an explicative factor in several models of international trade. In particular, financial resources play a critical role not only for firms' ordinary activities, but also for their growth and international expansion strategies (Chaney, 2013; Manova, 2012 and Melitz, 2003).
The literature has paid attention especially to the relationship between productivity and international trade, and although productivity is a key factor, this study also considers other critical financial variables: in specific, the need for financial resources that shows firms' financial health and constraints they may face (Forte and Moreira, 2018). Since the study of Greenaway et al. (2007), a growing number of investigations that study the relationship between financial variables and export activities have appeared.

These studies are based on the premise that financial health and financial capacities constitute a decisive role for the survival of firms in general and, especially, exporters. Several reasons could explain the necessity of financial resources for exporters (Chugan and Singh, 2016). Consequently, the factors that can make achieving their international strategy easier, or on the contrary, that can deter it, will be decisive in their international success because they can contribute to competing efficiently in those markets and to getting involved there in a stable manner.

Nevertheless, only a few studies tackle this question by considering that international firms are dissimilar and, consequently, they have a different exporting status that requires a detailed analysis (Gorg and Spaliara, 2012). Therefore, this research tries to show how financial variables, and consequently, financial health (Gorg and Spaliara, 2012), productivity and profitability affect firms' financial decisions, business survival and export success (Kiendrebeogo and Minea, 2016).

The main objective of this paper is to investigate the relationships between exporting success and financial capacities. To prove the role of the financial variables in such success, together with the measures proposed by the different models in relation to financial constraints, other variables that affect profitability, business growth and productivity have been incorporated. These last variables are incorporated because they can affect the ability to generate resources and, therefore, the access to financing. Somehow, they can be considered as indirect measures of the financial constraints.

Our empirical results confirm a positive relationship between export success, the age of the company, sales growth, dividend policy and the use of own resources.

MIRANDA-GARCIA, Marta, SEGOVIA-VARGAS, María Jesús, LUKASON, Oliver and VISSAK, Tiia. Financial Capacities and export success: Evidence from Small and Medium-Sized Estonian Firms. ECORFAN Journal-Mexico. 2019. 
The sample of our study consists of 242 Estonian exporters. Estonian exports have grown considerably in the last two decades (Figure 1). The 2008-2010 economic crisis that also negatively affected some exporters, was, at the same time, an incentive that encouraged several Estonian firms to enter international markets. In 2017 Estonian exports were 12.8 billion EUR, what represents an increase of $7.67 \%$ compared to 2016. Moreover, exports represent $55.69 \%$ of Estonian GDP, which situates Estonia in the 12th position (from 188 countries) in the export share ranking with respect to GDP.

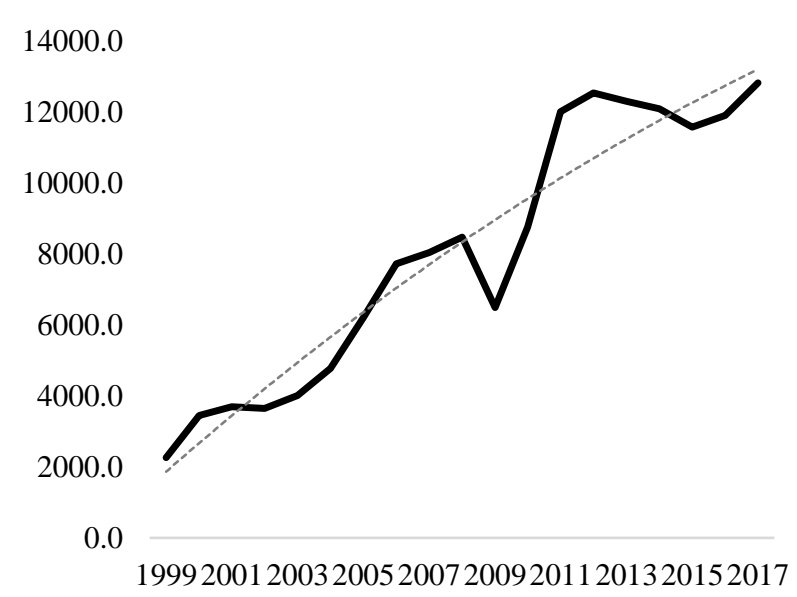

Figure 1 Estonia's exports in 1999-2017 (million EUR) Source: Own elaboration based on datosmacro.com (https://www.datosmacro.com/comercio/exportaciones/es tonia)

Despite its dynamic exporting activity, Estonia is a very small country: its population is only 1.3 million. The smallness of the country makes it an interesting research object as studying small countries is recommended (Schwens et al. 2018; Vissak, et al. 2018). Consequently, at present, studying Estonian firms' export performance is a relevant issue. Moreover, the results could be generalized to other countries that, independently of their size, have had very dynamic export activities in the last decades.

The sample of Estonian firms has been classified into two categories: successful and unsuccessful exporters (Landa-Torres, et al. 2012). For each firm, following the literature review, financial and economic information has been collected. We will focus on the following three sub-themes. First, we will characterize successful and unsuccessful international firms by describing exporters' financial features.
Second, for the set of previously classified firms, we will detect relationships between their financial variables and the success rate. Finally, bearing in mind that the variety and interdisciplinarity of analysis techniques enrich the results, we will carry out our study using two complementary methodologies. On one hand, we will apply a classical statistical technique (principal component analysis) to choose the most relevant variables among the ones selected from the literature. On the other hand, we will use an artificial intelligence method to discover the relations that characterize successful and unsuccessful export behavior.

The following section presents the literature review related to this subject including the research questions. The research sample, the variables and the methodology are presented thereafter. The following sections include the analysis of the results and the conclusions and future research suggestions.

\section{Literature Review: The importance of financial resources and financial variables for international performance}

Recent theoretical and empirical contributions point out the importance of financial development for international trade (Stiebale, 2011), although it is not very common to incorporate it to analyzing export performance (Maurel, 2009).

According to the literature, financial resources can affect the export result (Ling-Yee and Ogunmokun, 2001). Financial resources reflect the disposition of the necessary funds to carry out international transactions, but also firms' economic-financial structure (Maurel, 2008).

This structure may lead to the possession of capacities or strengths that allow them to have sufficient "financial health" to conduct the necessary investments to develop their international operations successfully. In short, the difference between internationally successful or unsuccessful companies can also have a financial dimension that can play a key role in exporting behavior (Chaney, 2005). 
That way, and following the previous research that encompasses these features (Greenaway et al, 2007, Berman and Héricourt, 2008; Maurel, 2009, 2008; Arndt et al., 2009; Bellone et al., 2010; Chaney, 2005), our paper considers that the financial structure, the structure of assets (economic structure), the capacity to generate cash flows and the productivity and growth of the company in the past can be linked a priori with its export performance. Even though it is not endorsed in all investigations (Berman and Héricourt, 2008), there may be significant relationships between the export result and certain indicators of profitability, financial and economic structure as pointed out by Maurel (2008).

Following Maurel's (2008) paper, the financial structure refers to sources of financing: shareholders' equity and debts. The shortage of financial resources and their cost can be a strong impediment to international development since this activity requires large investments, and financial sources can affect the achievement of a better export performance.

On the other hand, the economic structure refers to the composition of assets and is divided into two categories: non-current assets and current assets. The disposition of assets can influence export performance through the impact of export-related investments (Maurel, 2008). For example, we can point out the possible impact on the export result if the company has too many resources invested in clients, or if it possesses certain intangible assets such as patents and trademarks.

Finally, the ability to generate cash flows and the shortage of liquidity can slow down growth, especially in international markets, because exporting requires facing significant costs and restrictions that are associated with long payment periods and entry costs. A healthy economic and financial structure should cover those additional costs that cannot be avoided when foreign operations are conducted (Bernard and Jensen, 1999).

To assess firms' health or financial capacity, liquidity ratios, indebtedness ratios (Greenaway et al, 2007, Maurel, 2008, Arndt et al., 2009, Berman and Héricourt, 2008) and other financial structure ratios, which inform of the composition of financial sources and their distribution between debts and share capital, can be used.

ISSN-Print: 2007-1582- ISSN-On line: 2007-3682

ECORFAN $^{\circledR}$ All rights reserved.
The latter ratios can be interpreted as the capacity (or shortage) of obtaining financial resources and therefore, they can be used as a possible measure of firms' financial capacities or constraints (Berman and Héricourt, 2008).

Regarding the asset structure, the capital stock and the composition of assets (current and non-current), together with the ability to generate cash flows in the future as well as measures of productivity, and value added per worker (productivity) are relevant factors (Berman and Hericourt, 2008).

In fact, there is an important consensus in considering companies' productivity differences fundamental for explaining the existence of exporters (Arndt et al., 2009). The justification is that exporting can only be feasible if certain productivity thresholds are reached (Chaney, 2005). Therefore, we try to check if a specific economic-financial structure is associated with exporters' success (or failure). In this way, we can mention some of the aspects that have been discussed.

First, financial factors influence the decision to export because entering foreign markets can be considered as an investment (Melitz, 2003) associated with several additional costs. Significant evidence of this relationship has been obtained, concluding that only the most productive and largest companies can afford the costs associated with entering foreign markets (Melitz, 2003, Bernard and Jensen, 1999, Campa, 2004, Roberts and Tybout, 1997). This is consistent with the hypothesis that limited access to external financing can prevent companies from going abroad (Bellone et al. 2010).

Second, there is some evidence that exporters have a better financial situation than non-exporters, and this better situation is a result of participation in foreign markets rather than a determining factor for entering those markets (Greenaway et al, 2007). Some investigations explain how exporting can improve firms' financial position: for example, in terms of access to financing or lower liquidity constraints (Campa and Shaver, 2002). Additionally, exports can be considered a sign of efficiency and competitiveness for potential investors in an environment of information asymmetries linked to the imperfections of financial markets since only the best companies can export (Arndt et al., 2009).

MIRANDA-GARCIA, Marta, SEGOVIA-VARGAS, María Jesús, LUKASON, Oliver and VISSAK, Tiia. Financial Capacities and export success: Evidence from Small and Medium-Sized Estonian Firms. ECORFAN Journal-Mexico. 2019. 
In other words, not only can there be an improvement in financial health due to participation in foreign markets, but also that position can influence the export result. That relationship is to be determined in this study. There is an increasing interest in the role of financial constraints in international trade, from both a theoretic and an empirical point of view (see for example Manova, 2012, 2015; Muûls, 2015). Several studies show the relationship between external financing and international trade. For instance, Minetti and Zhu (2011) stated that rationing of credit can affect the decision to enter export markets and also export share. Bellone et al. (2010) found a negative relationship between financial health and export intensity as well as the type of export firms. Manova et al. (2015) showed how financial constraints affect firm-level exports and multinational activities.

Different measures and valuations of exporters' financial constraints are related, on one hand, to productivity (Melitz, 2003) and, on the other hand, to firms' ability to achieve profitability by means of cash flows. Access to credit and external financing (Muûls, 2015; Wagner, 2014) also affects firms' ability to follow investment opportunities (Almeida et al., 2004). Moreover, financial constraints depend on firms' financing preferences according to the Pecking Order Theory (Myers and Majluf, 1984). In the literature, firms' financial constraints, liquidity and leverage (Greenaway et al. 2007) are often used to represent higher or lower likelihood of credit restriction. Nevertheless, we will apply more complex and complete methodologies.

At this point, a literature review has been conducted looking for different proposals about how to measure financial constraints and their different effects on international activities (see, for instance Manova 2012; Manova et al., 2015; Wagner, 2014; Minetti, and Zhu, 2011; Musso and Schiavo, 2008; Williamson and Yang, 2016). In Table 1, the main models used to measure financial constraints are summarized.

\begin{tabular}{|c|c|c|}
\hline Study & Model & Variables \\
\hline $\begin{array}{l}\text { Kaplan and } \\
\text { Zingales, } \\
1997 \text { (first } \\
\text { approach). } \\
\text { Lamont et al. } \\
\text { (2001) (index } \\
\text { creation). }\end{array}$ & $K Z$ index & $\begin{array}{l}\text { Kit: capital stock (fixed } \\
\text { assets); } \\
\mathrm{CF}_{\text {it: the cash flow }} \\
\text { variable; Qit is the Tobins's } \\
\mathrm{Q} \text {; } \\
\mathrm{D}_{\text {it: the debt variable; }} \\
\text { TotCap }{ }_{\text {it: }} \text { the total capital } \\
\text { (sum of debt plus } \\
\text { stockholders' equity); } \\
\text { Divit: dividends } \\
\text { Cash } \\
\text { plus is the cash (cash } \\
\text { investments). short-term }\end{array}$ \\
\hline $\begin{array}{l}\text { Whited and } \\
\text { Wu (2006) }\end{array}$ & $\begin{array}{l}\text { Whited and } \\
W u \text { index } \\
\text { (WW index }) .\end{array}$ & $\begin{array}{l}\text { cash flow to total assets (- } \\
\text { ); } \\
\text { dividend policy indicator (- } \\
\text { ) } \\
\text { long-term debt to total } \\
\text { assets (+); } \\
\text { size (log of total assets or } \\
\text { market capitalization) (-); } \\
\text { the firm's three-digit SIC } \\
\text { industry sales growth (+); } \\
\text { sales growth (-) }\end{array}$ \\
\hline $\begin{array}{l}\text { Musso and } \\
\text { Schiavo } \\
(2008) \\
\text { (Bellone et } \\
\text { al.'s 2010 } \\
\text { contributions } \\
\text { are based on } \\
\text { this method) }\end{array}$ & & $\begin{array}{l}\text { size (total assets); } \\
\text { profitability (return on } \\
\text { total assets); } \\
\text { liquidity (current asset } \\
\text { over current liabilities); } \\
\text { cash flow generating } \\
\text { ability; } \\
\text { solvency (own funds over } \\
\text { total liabilities); } \\
\text { trade credit over total } \\
\text { assets; } \\
\text { repaying ability (financial } \\
\text { debt over cash flow) }\end{array}$ \\
\hline $\begin{array}{l}\text { Hadlock and } \\
\text { Pierce, } 2010\end{array}$ & $\begin{array}{l}\text { Size-age } \\
\text { methodology: } \\
\text { SA index }\end{array}$ & Assets; size; firm's age \\
\hline $\begin{array}{ll}\text { Stiebale, } & \text { J. } \\
(2011) & \end{array}$ & & $\begin{array}{l}\text { Liquidity ratio } \\
\text { Leverage } \\
\text { Short-term Leverage } \\
\text { Coverage Ratio } \\
\text { Cash-flow ratio } \\
\text { Size } \\
\text { Productivity } \\
\text { Total factor productivity } \\
\text { Reports Intangible assets } \\
\text { (yes/no) } \\
\text { Intangible assets } \\
\text { Tangible fixed assets } \\
\text { Export sales/total sales } \\
\text { Number of employees } \\
\text { Value added per employee } \\
\text { Sales per employee } \\
\text { Personal costs per } \\
\text { employee }\end{array}$ \\
\hline
\end{tabular}

Table 1 Models of financial constraints Source: Own Elaboration

As it has been pointed out, the results of other studies support several ideas. First, a company with limited financial resources is less likely to be competitive abroad. Export activity involves longer payment periods than the domestic trade (Ling-Yee \& Ogunmokun, 2001). 
Thus, companies must have a solid financial position to maintain their commercial activities. Second, export activity requires financial resources for its successful implementation and sustainability. Therefore, a company needs sufficient funds to be able to improve its production capacity, develop export specialists' skills and cover other operational costs such as transport risks or currency volatility. (Ling-Yee and Ogunmokun, 2001).

Thus, there is wide evidence that exporters outperform non-exporters in many aspects, which means that companies must have a certain level of liquidity and productivity to start exporting. This is called the "self-selection" hypothesis or effect. Only the most productive companies can start exporting (Melitz, 2003; Battaglia, et al., 2018). The debate on this matter is intense; however, the causality can go in the opposite direction. In this sense, empirical evidence on the reverse causality, the so-called "learning for export" hypothesis, is less extended (Greenaway and Kneller, 2007).

Thus, starting from the assumption that financial variables affect exporters during their whole life cycle, the following research question is developed:

\section{Which financial variables distinguish successful and non-successful exporters?}

This also allows us to show how a combination of financial variables (the ones that are included in the models of financial restrictions -direct measures of financial constraints- together with the ones related to profitability, business growth and productivity -indirect measures of financial constraints) reflects in different status of exporting companies.

\section{Sample, variables and research methodology}

\section{Sample and variables}

This study is based on firm-level data from the Estonian Business Register's database of annual financial reports. It contains financial and economic information for 242 Estonian firms for the period 2009-2013. Only manufacturing firms were analyzed, as such firms are the most active exporters (Lejárraga and Oberhofer, 2015; Vissak, et al. 2018).
To measure the international performance of the sample firms, following the literature, two variables have been selected: export intensity (export ratio) and export growth rate for the period of 2009-2013 (Czinkota and Ursic, 1991; Shoham, 1996). Both measures provide a reasonable description of export performance and capture the complexity of the export process and its success (Landa-Torres, 2012). The combination of both indicators allows us to classify the firms in different categories, according to the rate of success or failure (Figure 2).

\begin{tabular}{|c|l|l|}
\hline $\begin{array}{c}\text { Export intensity } \\
\text { (exports/total net sales in } \\
\text { percentage) }\end{array}$ & \multicolumn{2}{|c|}{$\begin{array}{c}\text { Export growth rate last five years } \\
\text { (in percentage)s }\end{array}$} \\
\hline Oncrease & $\begin{array}{c}\text { Non increase } \\
\text { or decrease }\end{array}$ \\
\hline Equal or less than 15\% & Success & No success \\
\hline & Non-success. & No success \\
\hline
\end{tabular}

Figure 2 Matrix Intensity/Growth

Source: Own Elaboration based on Czinkota and Ursic (1991)

Our choice of explanatory variables was guided by prior approaches to measuring constrains (see Table 1). Originally, the list of dependent variables consisted of all the variables used in the models of financial constraints, especially Musso and Schiavo (2008). Consequently, 31 independent variables were calculated. Due to the missing information about some firms' independent variables, the final sample consisted of 121 companies, 82 were "successful" and the rest (39 firms) "unsuccessful", with 31 variables calculated.

Due to the large number of variables in relation to the final sample (121 firms), it was necessary to check the sample's suitability for the analysis. Therefore, factor analysis was conducted. Principal Components Analysis (PCA) allowed us to check the percentage of variance that the 31 variables explained. The statistical tests evaluating the suitability of the sample to the model showed excellent adequacy of the data, because KMO statistic, which indicates the proportion of the variance that the analyzed variables have in common, had a value of 0.883 . Thus, data were suitable for the factor analysis. Also, by applying Bartlett's test we could assure that factor analysis can be used: the significance was perfect since it had the value 0.00. Finally, another factor to consider is the determinant of the correlation matrix that presented a value of 5.97E-015. 
As it was very close to 0 , this suggested a high level of multicollinearity in the set of variables involved in the matrix. We initially selected five factors, which included 27 variables that had eigenvalues $\geq 1$ indicating that the component explained more variance than a variable alone. These five components explained $72.531 \%$ of the variance.

\begin{tabular}{|l|l|ll|}
\hline \multicolumn{4}{|c|}{ Initial Eigenvalues } \\
Component & Total & $\%$ variance & $\%$ accumulated \\
\hline 1 & 12,144 & 44,979 & 44,979 \\
\hline 2 & 3,198 & 11,846 & 56,825 \\
\hline 3 & 1,805 & 6,685 & 63,510 \\
\hline 4 & 1,399 & 5,181 & 68,691 \\
\hline 5 & 1,037 & 3,840 & 72,531 \\
\hline
\end{tabular}

Table 2 Total variance explained

Source: Own Elaboration

Component 1 (equity, total assets, cash stock, total stock, working capital, CAPEX, short liability, financial debt, long-term debt, retained earnings, cashflow, current assets, tangible fixed assets, total liabilities, earnings before interest and taxes, sales, net income and number of employees) was the most relevant since it explained $45 \%$ of the variance. This component grouped the variables of economic and financial structure (economic structure of current assets), and how they interacted to generate profitability.

Concretely, in this first component, the variables that saturated more were those related to the size of the company (measured in terms of total assets and sales), liquidity (current assets and cash flow) and companies' short-term solvency (due to working capital and short-term debt stand out). The component 2 added interest payment variable because the attributes with greater weight were those linked to long-term debt and its cost, whilst the most relevant variables in component 3 (sales growth, ROA, value added per employee, productivity and dividend policy) were those variables related to companies' economic performance and productivity. In component 4, variables of different nature appeared (industry growth and wages), but the most relevant was the growth of the industry that can be considered a proxy of business opportunities in a certain sector. Finally, in component 5, the variable with the greatest weight was companies' age, which can be considered a proxy of experience but also of financial restrictions, as we have indicated.
To maintain the explanatory power, we eliminated six variables, as the same information was also provided by other variables:

- $\quad$ Number of employees and sales level were removed since we kept the total assets variable as a measure of the company's size.

- The current assets variable was eliminated due to the breakdown of liquid assets and stocks.

- Tangible fixed assets variable was eliminated since the investment made in non-current assets was included.

Total liabilities were removed as we included the short- and long-term liabilities.

- $\quad$ Earnings before interest and taxes variable was also eliminated as ROA, on one hand, and the cash flow, on the other, were included.

Thus, PCA allowed us to reduce the original number of variables to 21 (Table 3 ) and to perform the classification with a reasonable number of factors. We checked in PCA that the five initial factors with eigenvalues greater than 1 or near 1 , continued to explain about $71 \%$ of the variance, which is an acceptable figure.

\begin{tabular}{|c|c|}
\hline Variable & Definition \\
\hline \multicolumn{2}{|l|}{ Control Variables } \\
\hline Industry_growth & 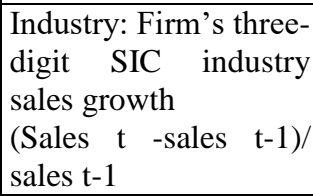 \\
\hline Years. & $\begin{array}{l}\text { Age of the firm: } \\
\text { number of years since } \\
\text { the firm was founded }\end{array}$ \\
\hline Total_assests & $\begin{array}{lll}\text { Total assets } & \text { (firm's } \\
\text { size) } & & \end{array}$ \\
\hline \multicolumn{2}{|l|}{ Solvency and Liquidity variables } \\
\hline Cashflow & Operating cash flow \\
\hline cash_stock & Cash \\
\hline total_stock & Stocks \\
\hline WC_CA & working capital \\
\hline CAPEX & $\begin{array}{l}\text { Capital Expenditures: } \\
\text { exact amount of } \\
\text { money the firm in a } \\
\text { specific year has spent } \\
\text { to purchase new fixed } \\
\text { assets (proxy) }\end{array}$ \\
\hline long-term debt & long-term debt \\
\hline Sh_Liab & short-term deb \\
\hline Financ_Debt & $\begin{array}{l}\text { Financial debt: the loans } \\
\text { with the banks (short- } \\
\text { term and long term) and } \\
\text { the issue of bonds. In case } \\
\text { there is no information of } \\
\text { the bonds issues, just the } \\
\text { bank loans are } \\
\text { considered. }\end{array}$ \\
\hline
\end{tabular}

MIRANDA-GARCIA, Marta, SEGOVIA-VARGAS, María Jesús, LUKASON, Oliver and VISSAK, Tiia. Financial Capacities and export success: Evidence from Small and Medium-Sized Estonian Firms. ECORFAN Journal-Mexico. 2019. 


\begin{tabular}{|c|c|}
\hline Dividend_policy & $\begin{array}{l}\text { Dividend policy } \\
\text { indicator: Dummy } \\
\text { variable that takes } 0 \text { in } \\
\text { case of not dividend } \\
\text { policy; or } 1 \text { if there is } \\
\text { dividend policy. }\end{array}$ \\
\hline Interest_payment & $\begin{array}{l}\text { Payments of interests: } \\
\text { This is a proxy of } \\
\text { annual accrual based } \\
\text { interest expense. }\end{array}$ \\
\hline Retained_earnings & $\begin{array}{l}\text { Retained earnings: } \\
\text { This is the maximum } \\
\text { amount of resources } \\
\text { that a firm can devote } \\
\text { to self-financing }\end{array}$ \\
\hline Equity & Shareholders' funds \\
\hline $\begin{array}{l}\text { Variables related to profitability } \\
\text { and growth }\end{array}$ & \\
\hline Sales_growth & $\begin{array}{l}\text { Sales growth: (Sales t- } \\
\text { sales t-3)/ sales t-3 }\end{array}$ \\
\hline ROA & $\begin{array}{l}\text { Profitability: Return } \\
\text { On Assets }\end{array}$ \\
\hline \multicolumn{2}{|l|}{ Net_income } \\
\hline Val_added & $\begin{array}{l}\text { Value added per } \\
\text { employee. It is } \\
\text { calculated in the } \\
\text { following way: sales + } \\
\text { other operating } \\
\text { revenues-cost of goods } \\
\text { sold -operating } \\
\text { expenses (without } \\
\text { amortization). This } \\
\text { result is divided by the } \\
\text { number of employees }\end{array}$ \\
\hline Wage & Wage level \\
\hline Productivy & $\begin{array}{l}\text { Value added. It is } \\
\text { calculated in the } \\
\text { following way: sales + } \\
\text { other operating } \\
\text { revenues - cost of } \\
\text { goods sold-operating } \\
\text { expenses (without } \\
\text { amortization). This } \\
\text { result is divided by the } \\
\text { wage }\end{array}$ \\
\hline
\end{tabular}

Table 3 Definition of independent variables Source: Own Elaboration

As we can see, the list of independent variables used to classify successful and unsuccessful companies covered most of the elements of the most common indexes such as Kaplan-Zingales, Whited-Wu and MussoSchiavo. Additionally, in our model we also intend to encompass several dimensions, not only the financial profile (that is, the financial capacities reflected in the capital structure) of the company but also of the economic one (that is, the profitability, business growth and productivity that are indirect indicators of the financial constraints).
Thus, we refer to several components of the long-term solvency of the company, liquidity, the company's ability to generate profitability and business opportunities and growth, efficiency and productivity as well as characteristics of the workforce. Liquidity and solvency refer to the ability of a company to pay its short-term obligations, and generate liquidity quickly, as well as the ability to meet its longterm financial obligations.

Normally, financial constraints have been assessed in terms of restricted access to external funds or low productivity for generating internal resources (Kiendrebeogo and Minea, 2016). However, as it has been pointed out by Bellone et al. (2010), there is no clear relationship between liquidity, leverage and financial restrictions as companies can have enough liquidity, but nevertheless, present a complicated financial situation or have a lot of liquidity because they cannot access external resources. Almeida et al. (2004) also pointed out that companies with limited financial resources normally accumulate cash, and therefore, liquidity is associated with financial constraints. The same happens with bankruptcy that could be a sign of limited access to external resources. Also, on the other hand, the payment of dividends has been related to companies with lower financial restrictions than those that do not pay dividends (Fazzari et al., 1988).

In terms of efficiency, we intend to measure the capacity to produce profitably and how efficiently a company uses its resources. In terms of profitability, we refer to the ability to generate profits. Regarding the variable wages, it expresses the variations between companies in terms of qualifications (Wagner 2012), but also the differences in production costs (Stiebale 2011). Consequently, salaries are negatively correlated with firms' competitiveness and this fact penalizes the participation of companies in international markets. However, higher salary levels can reflect workers' higher qualification, so this can also have a positive effect on export success.

Finally, other variables that have appeared in the previous models and that have been considered as relevant, were added as control variables. These variables are the age and the size of the company. Size and age are associated with the probability of exporting but also with companies that are less financially constrained (Hadlock and Pierce, 2010).

MIRANDA-GARCIA, Marta, SEGOVIA-VARGAS, María Jesús, LUKASON, Oliver and VISSAK, Tiia. Financial Capacities and export success: Evidence from Small and Medium-Sized Estonian Firms. ECORFAN Journal-Mexico. 2019. 


\section{Research Methodology}

Nowadays the complexity of financial problems requires a new approach to tackle them. In this new context, new techniques have appeared, among them the so-called Data Mining (DM) techniques. DM techniques are algorithms that can deduce relationships among different attributes, variables or concepts to help in the decision-making process, among other questions. DM can be defined as the analysis of data sets observed to find unsuspected relationships and to summarize the data in a new form that can be useful and understandable (Hand et al. 2001). Data mining techniques have proliferated in several fields such as finances, industry, commerce, telecommunications and services and, even in medicine. As we can see, all these sectors require advanced techniques to obtain useful information due to the huge amount of data that they frequently manage. In fact, the final objective consists in "turning data into knowledge".

Data mining techniques can be divided into two groups: statistical techniques and methods that belong to Artificial Intelligence (AI). The techniques that solve problems using artificial intelligence are called Soft-computing techniques. Consequently, in recent years, together with statistical techniques (discriminant analysis, logit or probit), there is a new approach to tackle with many problems, the financial ones among them, based on soft computing techniques. AI tools are very useful. In some cases, they are complements, and even an alternative to the statistical methods as they overcome some of their problems when the variables do not satisfy the required statistical assumptions (Korol, 2013). In any case, they can give a new approach to the financial problems that are dealt with these new methodologies.

Once the use of artificial intelligence methods has been justified in general, it would be desired to choose a criterion to select the most suitable one to solve our problem. Sometimes, the utility of the knowledge generated by the data mining techniques is directly related to the understanding of the obtained model. Some of them are explicative methods: the obtained model is directly understandable by the final users, even if they are not experts in the method (rule induction algorithms and decision trees).
Others follow a "black box" approach: the knowledge that they generate is not directly understandable or easy to analyze by the final users (it is implicit), such as in neural networks or support vector machines. Due to the characteristics of the considered problem and the fact that, normally, its final user is not an expert in data mining techniques, it is important that the obtained model must be understandable. So, explicative artificial intelligence techniques will be used to identify the role of financial variables in export success, concretely, a rule induction algorithm.

The rule induction algorithms developed their models in the form of logical sentences: if $\ldots$ conditions $\ldots$ then $\ldots$ decisions. If some conditions (ratios, attributes or variables) are satisfied then the firm belongs to a determined category (decisions). Consequently, the rules are understandable by the final user and the conclusions derived by the data are easily explainable. Each decision rule has a specific strength: the number of objects that satisfy the condition part of the rule and, this way, they belong to the class or category indicated by the rule.

Next, a brief description of the methodology is presented. PART algorithm (developed by Frank and Witten, 1998) has been defined as a rule-learning algorithm based on partial decision trees algorithm that eliminates some of the paths found in an initial decision tree structure. Therefore, we could state that it "combines" a decision tree and a rule learning algorithm. In short, PART aims at the most general rule by choosing the leaf that covers the greatest number of instances. The combination of both strategies adds flexibility and speed to PART (for more details, see Frank and Witten, 1998). Additionally, in our experience PART is more accurate and simple than other fast rule induction what makes it more suitable than others to the problem we are studying (Camacho et al., 2015; Muñoz-Izquierdo et al., 2019).

\section{Results and Discussion}

The final sample of 121 firms described by the 21 dependent variables shown in Table 3 will be used to carry out our analysis. 


\section{Part Model}

The PART model has been developed using WEKA (data-mining package developed by Waikato University (Witten and Frank, 2005) and available

at https://www.cs.waikato.ac.nz/ml/weka/). The percentage of correctly classified firms is $73 \%$ (cross-validation procedure), which allows us to interpret the rules. Figure 3 shows Part model rules.

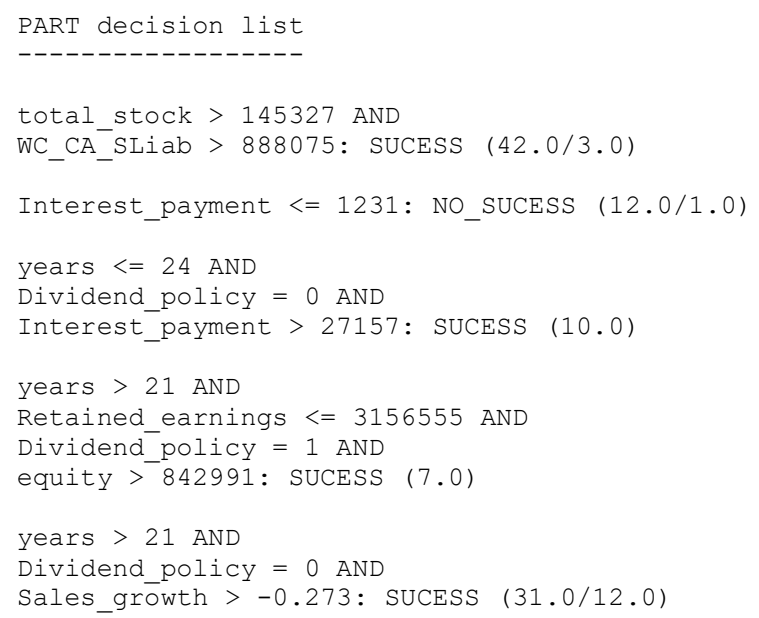

Figure 3 Part Decision List

Source: Own Elaboration. The model can be read in the following way: Rule 1 "if the total stock is greater than 145,327 and the working capital is greater than 888,075 then the firm belongs to the success class. This rule is supported by 42 firms with three exceptions" and so on.

Although the original number of variables is 21 , the five rules only contain eight variables. Therefore, the rest could be considered as redundant. Focusing on these variables, in this model the relevant variables are those related to the liquidity of assets, showing that there is a positive relationship between export success and working capital requirements and stocks if these surpass levels that are not excessively high (considering the average values of these variables).

This result suggests that considering that success in international markets is reflected in a greater export intensity and a growth in foreign sales, this success should be achieved by serving customers abroad adequately, which could force them to maintain a certain level of stocks as well as more investment in working capital (Wagner, 2014). The second rule refers to the payment of interest for financial debt. The PART shows that if this variable is lower than the beforementioned level (see Figure 3), companies have difficulties in achieving success.
This result means that although interest payment affects the liquidity of the company, if this payment is low, a company may experience difficulties of accessing external financing and, therefore, it may have financial restrictions. The third rule, like the previous one, does not present a great strength, but it relates three variables: age, interest payments and dividend policy, which draws a profile on financial restrictions. So, companies with a certain level of maturity (considering that the minimum is 19 and the maximum is 28 years) that can access external resources even if they do not pay dividends, can achieve success.

In the same line, we find the fourth rule and fifth rule, in which we continue to link success to companies that do not have financial restrictions as they can generate sufficient resources with their own activity. These resources are represented by the payment of dividends and by having a certain level of capital or achieving a certain level of growth.

The last rule indicates that the age itself can be an impediment to achieving success. Considering that the average age of the companies in the sample is 24 years and given the results of the previous rules, we found that age does not present a linear relationship with success. The more mature companies may not achieve success in international markets, and they can even exit from these markets. The resources of a company as well as its capabilities are determined by the pattern of its past behavior (Teece et al., 1997) that can create barriers and dependencies that can condition and limit the actions in the future. Thus, compared to older companies, the new ones are not subject to these procedures or traditions, which can be a stimulus to make decisions with greater freedom, take risks and adopt an entrepreneurial orientation that can lead to better results in foreign markets (Balabanis and Katsikea, 2003).

\section{Robustness}

To ensure the viability of our results, we have performed a robustness check with another artificial intelligence rule induction algorithm: rough set theory that has been used to solve other financial problems (Segovia-Vargas et al., 2015; Camacho-Miñano et al., 2015). The rough set theory was firstly introduced by Pawlak (1991). 
It is a mathematical method that identifies dependencies among attributes and searches for association rules with them to solve a classification problem. Two relevant concepts in this methodology are the reduct and the core. The reduct is the minimal subset of attributes that provides the same classification as the set of all attributes. If there is more than one reduct, the intersection of all of them is the core and is the collection of the most relevant attributes in the table.

The rough set model has been carried out
using RSES (available at https://www.mimuw.edu.pl/ szczuka/rses/start. html). The classification accuracy equaled $76.1 \%$ (cross-validation procedure). This figure was quite similar to the one obtained by PART, so this evidence suggests that our results are robust. The Rough Set model was quite complex compared with PART and the core was empty, confirming that no single variable could explain the successful or unsuccessful model. However, focusing on the selected variables in the reducts, one of the most relevant variables was sales growth, that also appeared in the PART model, what would confirm the importance of this variable in the success in international markets.

\section{Conclusions}

The objective of this paper is to investigate the relationships between exporting success and financial constraints using several measures of financial constraints and other variables that affect profitability, business growth and productivity that can affect the ability to generate resources and, therefore, the access to financing. The incorporation of all these variables will allow us to determine a financial and economic profile of export behavior as completely as possible, given the complexity of the phenomenon and following the recommendations of previous investigations.

For this purpose, we incorporated several variables to characterize the multiple dimensions of the phenomenon: the economic or investment structure of the company, the financial structure as well as some other aspects such as the company's growth measures, the efficiency and the profitability of the company (Lages 2000 and Lages et al. 2008).
One of the lines of research that has been suggested to overcome some of these drawbacks has been the use of new techniques and methodologies based on the experimentation (Leonidou et al. 2010) and this is among the main contributions of this paper. We analyzed the export phenomenon with methods of artificial intelligence: in this case, by means of the rule induction algorithm PART, which allowed us to study the internationalization process from a more realistic, global and integrating approach and with more sophisticated quantitative analysis techniques.

These methodologies have been gradually and successfully incorporated into the analysis of other economic and financial problems (Tay and Shen, 2002) and enable studying the export process from an unprecedented perspective not previously applied by other scholars.

Thus, from the methodological perspective and given the results obtained with the PART algorithm, it can be concluded that this method was appropriate to carry out the descriptive analysis that allowed classifying exporting companies into successful and unsuccessful according to the attributes included in the research. These variables reflect the complex nature of the business decision-making process, especially in firms' internationalization where there are many factors to consider. These factors can describe export behavior, on one hand, and, on the other hand, to relate the descriptions of exporting companies with decisions about their classification.

Firstly, we will point out the most important results. From the economic point of view, we found that the way to international success (or failure) in general not only follows a path but can be also reached via different routes. Each of these possibilities will show a greater relevance of some characteristics over others and what is more important, the combination, adjustment or interrelation between these factors makes up each of the possible alternatives. Thus, with the results obtained in this research, we can point out that although there are more significant financial factors than others, none of them is clearly a key factor for all companies and situations. 
Consequently, as it has been emphasized by Robertson and Chetty (2000, p. 214), following the contingency and strategic adjustment approach "there is no good or bad factor in relations to others, but each one of them can be more appropriate depending on the context in which they are used".

We also showed that it is easier to identify the financial characteristics of successful exporters than companies classified as unsuccessful. The rules associated with class 1 (success) have greater strength and coverage. It is very interesting to understand these relationships as they would help companies to correct certain actions and strategies and avoid failure (even exiting export markets) and, on the other hand, the stakeholders in export companies (investors, governments and financial institutions among others), could choose properly the actions and investments to be made. These results, therefore, show that although the road to success is more complex due to the variety of obtained rules, it is equally useful to know the decisions that can lead to failure in export activity.

Another important advantage of the method is its ability to discover knowledge. In our case, the common patterns of export success and failure reveal the direct or indirect relationships that may exist between the variables, but also provide in a concrete and specific manner (the way and the value that these variables must take) that classification occurs in one of the classes: success or failure. This is important because it obtains a high degree of detail and concreteness that can be used in subsequent investigations to perform partial analyses of certain variables and situations, and as it creates a true "recipe booklet" of how to achieve the desired export result.

In general, no decision rules contain just a single variable. Therefore, it is important to note that there is no condition or characteristic which automatically constitutes a sufficient condition for success. In other words, no single factor leads to success or failure. The use of own funds and the growth in total sales of the company are relevant since they appear frequently. The last result confirms the relationship between this variable and export behavior.
Therefore, past results can affect companies' decisions and future actions and, moreover, the (dis)satisfaction with past results can cause changes in foreign activities to the extent that the perception of risk and the strategic orientation will also change. Previous results influence companies' strategy and future exporting behavior. In addition, this fact is linked to the learning process as organizations incorporate experience into their actions in a way that will guide future behavior in relation to taking risks, innovation, and adaptation to the target market (Lages et al., 2008).

The most productive and growing companies are those that can afford the costs associated not only with foreign market entry, but also with export permanence. To the extent that exporting can be considered a market diversification strategy, it is linked to the idea that any strategic option requires resources. In future research, it would be interesting to explore this recursive process not sufficiently researched in the field of exports.

Similarly to other studies, this paper is not short of limitations. Our main limitation has been the sample size, as it was reduced to analyze the maximum number of variables suggested by the literature review. It was impossible to get all the relevant variables for all the firms. Consequently, larger samples should be studied in the future. Finally, our results have practical implications for managers and economic policy makers.

Companies should follow a path of growth and profitability and use internal and external financing (if it is accessible and available) to increase their export intensity, since it allows developing a sustainable export strategy. The availability of these financial resources allows companies to finance the investments required for export.

\section{Acknowledgements}

This work was supported by the Institutional Research Funding IUT20-49 of the Estonian Ministry of Education and Research and by the Estonian Research Council's grant PUT 1003. 


\section{References}

Almeida, H., Campello, M., \& Weisbach, M. S. (2004). The cash flow sensitivity of cash. The Journal of Finance, 59(4), 1777-1804.

Arndt, C., Buch, C. \& Mattes, A. (2009). Barriers to internationalization: firm-level evidence from Germany. IAW Diskussionspapiere, No. 52, September, 35 p. Available in http://bruegel.org/wpcontent/uploads/2015/09/EFIGEWP9.pdf

Balabanis, G. I. \& Katsikea, E. S. (2003). Being an entrepreneurial exporter: does it pay? International Business Review, 12, 233-252.

Battaglia, D., Neirotti, P., \& Paolucci, E. (2018). The role of $R \& D$ investments and export on SMEs' growth: a domain ambidexterity perspective. Management Decision, Vol. 56 Issue: $\quad 9$, pp. 1883-1903. https://doi.org/10.1108/MD-02-2017-0136

Bassetto, C. F., \& Kalatzis, A. E. (2011). Financial distress, financial constraint and investment decision: Evidence from Brazil. Economic Modelling, 28(1), 264-271.

Bellone, F., Musso, P., Nesta, L. \& Schiavo, S. (2010). Financial constraints and firm export behaviour. The World Economy, 33, 347-373.

Berman, N., \& J. Hericourt (2008). Financial factors and the margins of trade: evidence from cross-country firm-level data. Documents de Travail du Centre d'Economie de la Sorbonne 2008.50. Paris.

Bernard, A. \& Jensen, J.B. (1999), Exceptional exporter performance: cause, effect, or both? Journal of International Economics, 47 (1), 125.

Camacho-Miñano, M.M., Segovia-Vargas, M. J. \& Pascual-Ezama, D. (2015) Which characteristics do the insolvent firms have to get survival? A SME reorganization prediction model. Journal of Small Business Management 53 (2), 340-354

Campa, J. (2004). Exchange rates and trade: How important is hysteresis in trade?. European Economic Review, 48 (3), 527-548.
Campa, J.-M. \& Shaver, J.-M., (2002). Exporting and capital investment: on the strategic behavior of exporters. Discussion Paper, 469. IESE Business School, University of Navarra.

Castro, F., Kalatzis, A. E., \& Martins-Filho, C. (2015). Financing in an emerging economy: Does financial development or financial structure matter? Emerging Markets Review, 23, 96-123.

Chaney, T. (2005). Liquidity Constrained Exporters. University of Chicago. Mimeo.

Chugan, P. K., \& Singh, S. (2016). Impact of type of export finance on firms' export profitability: a study of industrial clusters in Gujarat, India. In N. Delener, L. Fuxman, F. V. Lu, \& S. Rodrigues (Eds.). Exceeding the vision: innovate, integrate and motivate" (pp. 89-96), NewYork: Global Business and Technology Association (GBATA).

Cleary, S., Povel, P. \& Raith, M. (2007). The Ushaped investment curve: theory and evidence. Journal of Financial and Quantitative Analysis, $42,1-40$.

Czinkota, M.R. \& Ursic, M.L. (1991). Classification of exporting firms according to sales and growth into a share matrix, Journal of Business Research, 22, 241-253.

Dimitras, A., Slowinski, R., Susmaga, R., \& Zopounidis, C., 1999. Business failure prediction using Rough Sets. European Journal of Operational Research, 114, 263-280.

Fazzari, S., Hubbard, R., \& Petersen, B. (1988). Financing constraints and corporate investment. Brookings Papers on Economic Activity, 19(1), 141-195.

Frank, E., \& Witten, I. H. (1998). Generating accurate rule sets without global optimization. ICML'98 Proceedings of the Fifteenth International Conference on Machine Learning, pp. 144-151.

Forte, Rosa \& Moreira, Ana Salomé. (2018). Financial Constraints and Small and MediumSized Firms' Export Propensity: Evidence from Portuguese Manufacturing Firms. International Journal of the Economics of Business, 25:2, 223241.

MIRANDA-GARCIA, Marta, SEGOVIA-VARGAS, María Jesús, LUKASON, Oliver and VISSAK, Tiia. Financial Capacities and export success: Evidence from Small and Medium-Sized Estonian Firms. ECORFAN Journal-Mexico. 2019. 
Gorg, H. \& Spaliara, M.-E. (2013). Export market exit, financial pressure and the crisis. Working Paper 9599, CEPR.

Greco, S., Matarazzo, B., \& Slowinski, R. (1998). A new rough set approach to evaluation of bankruptcy risk. In C. Zopounidis (Ed.), New operational tools in the management of financial risks (pp. 121-136). Dordrecht: Kluwer Academic Publishers.

Greco, S., Matarazzo, B., \& Slowinski, R. (2001). Rough sets theory for multicriteria decision analysis. European Journal of Operational Research, 129(1), 1-47.

Greenaway, D. \& Kneller, R. (2007). Firm heterogeneity, exporting and foreign direct investment, Economic Journal, 117 (517), 134161.

Greenaway, D., Guariglia, A. \& Kneller, R. (2007). Financial factors and exporting decisions. Journal of International Economy, 73, 377-395.

Guo, Z., \& Luo, Y. (2017). Credit constraint exports in countries with different degrees of contract enforcement. Business and Economic Research, 7(1), 227-241.

Hadlock, C. J., \& Pierce, J. R. (2010). New evidence on measuring financial constraints: Moving beyond the KZ index. The Review of Financial Studies,23(5), 1909-1940.

Hand, D., Mannila, H. \& Smyth, P. (2001). Principles of Data Mining. Cambridge, MA: The MIT Press.

Harris, R. I., \& Li, Q. C. (2011). The determinants of firm exit from exporting: Evidence for the UK. International Journal of the Economics of Business, 18(3), 381-397.

Kaplan, S. N., \& Zingales, L. (1997). Do investment-cash flow sensitivities provide useful measures of financing constraints? The Quarterly Journal of Economics, 112(1), 169215.

Katsikeas, C. S., Leonidou, L. C., \& Morgan, N. A. (2000). Firm-level export performance assessment: review, evaluation, and development. Journal of the Academy of Marketing Science, 28(4), 493-511.
Kiendrebeogo, Y., \& Minea, A. (2016). Financial factors and manufacturing exports: Firm-level evidence from Egypt. The Journal of Development Studies, 53(12), 1-17.

Korol, T. (2013). Early warning models against bankruptcy risk for Central European and Latin American enterprises. Economic Modelling, 31, 22-30.

Lages, L. F., Jap, S. D. \& Griffith, D. (2008). The role of past performance in export ventures: a short-term reactive approach. Journal of International Business Studies, 39 (2), 304-325.

Lages, L. F. (2000). A conceptual framework of the determinants of export performance: reorganizing key variables and shifting contingencies in export marketing. Journal of Global Marketing, 13(3), 29-51.

Laitinen, E. K. (1992). Prediction of failure of a newly founded firm. Journal of Business Venturing, 7(4), 323-340.

Landa-Torres, I., Ortiz-Garcia, E. G., SalcedoSanz, S., Segovia-Vargas, M. J., Gil-Lopez, S., Miranda, M., Leiva-Murillo, J. M., \& Del Ser, J. (2012) Evaluating the Internationalization Success of Companies through a Hybrid Grouping Harmony Search - Extreme Learning Machine Approach, (2012) IEEE Journal of Selected Topics in Signal Processing, 6(4), 388398.

Lamont, O., Polk, C., \& Saaá-Requejo, J. (2001). Financial constraints and stock returns. The Review of Financial Studies, 14(2), 529554.

Lejárraga, I., \& Oberhofer, H. (2015). Performance of small-and medium-sized enterprises in services trade: Evidence from French firms. Small Business Economics, 45(3), 673-702.

Leonidou C., Katsikeas C. \& Coudounaris D. (2010). Five decades of business research into exporting: a bibliographic analysis. Journal of International Management, 16, 78-91.

Lima, V., López, F., \& Vallelado, E. (2014). Financial constraints for investment in Brazil. International Journal of Managerial Finance, 10(1), 73-92. 
Ling-Yee, L. \& Ogunmokun, G. O. (2001). The influence of interfirm relational capabilities on export advantage and performance: an empirical analysis. International Business Review, 10, 399-420.

Manova, K. (2012). Credit constraints, heterogeneous firms, and international trade. Review of Economic Studies, 80(2), 711-744.

Manova, K., Wei, S. J., \& Zhang, Z. (2015). Firm exports and multinational activity under credit constraints. Review of Economics and Statistics, 97(3), 574-588.

Maurel, C. (2008). Financial approach to export performance in French wine SMEs. 4th International Conference of the Academy of Wine Business Research, Siena, 17-19 July.

Maurel, C. (2009). Determinants of export performance in SMEs: The case of the French wine industry. International Journal of Wine Business Research, 21(2), 118-142.

Mckee, T. (2000). Developing a bankruptcy prediction model via rough sets theory. International Journal of Intelligent Systems in Accounting, Finance and Management, 9, 159173.

Melitz, M. J. (2003). The impact of trade on intra-industry reallocations and aggregate industry productivity. Econometrica, 71(6), 1695-1725.

Minetti, R. \& Zhu, S. (2011). Credit constraints and firm export: Microeconomic evidence from Italy. Journal of International Economics, 83, 109-125.

Muñoz-Izquierdo, N., Camacho-Miñano, M. D. M., Segovia-Vargas, M. J., \& Pascual-Ezama, D. (2019). Is the external audit report useful for bankruptcy prediction? Evidence using artificial intelligence. International Journal of Financial Studies, 7(2), 20.

Musso, P., \& Schiavo, S. (2008). The impact of financial constraints on firm survival and growth. Journal of Evolutionary Economics, 18(2), 135-149.

Muûls, M. (2015). Exporters, importers and credit constraints. Journal of International Economics, 95(2), 333-343.
Myers, S. C., \& Majluf, N. S. (1984). Corporate financing and investment decisions when firms have information that investors do not have. Journal of Financial Economics, 13(2), 187-221.

Pawlak, Z. (1991). Imprecise categories, approximations and rough sets. In Pawlak, Z. (Ed.). Rough sets (pp. 9-32). Springer, Dordrecht.

Ponikvar, N., Kejžar, K. Z., \& Peljhan, D. (2018). The role of financial constraints for alternative firm exit modes. Small Business Economics, 51(1), 85-103.

Roberts, M. \& J. Tybout (1997). The decision to export in Colombia: An empirical model of entry with sunk costs. American Economic Review, 87(4), 545-564.

Schwens, C., Zapkau, F.B., Bierwerth, M., Isidor, R., Knight, G. \& Kabst, R. (2018), International entrepreneurship: A Meta-analysis on the internationalization and performance relationship, Entrepreneurship Theory \& Practice, https://doi.org/10.1111/etap.12280

Segovia-Vargas, M.J., Camacho-Miñano, M.M. \& Pascual-Ezama, D. (2015). Risk factors selection in automobile insurance policies: A way to improve the bottom line of insurance companies. Revista Brasileira de Gestão de Negócios-RBGN, 17 (57), 1228-1245.

Shoham, A. (1996). Marketing-mix standardization: determinants of export performance, Journal of Global Marketing, 10 (2), 53-73.

Spaliara, M. E., \& Holger, G. (2012). Financial health, exports, and firm survival: Evidence from UK and French firms. Economica, 81, 419444.

Stiebale, J. (2011). Do financial constraints matter for foreign market entry? A firm-level examination. The World Economy, 34(1), 123153.

Tay, F.E.H. \& Shen, L. (2002). Economic and financial prediction using rough sets model. European Journal of Operation Research, 141(1), 641-659. 
Teece, D. J., Pisano, G., \& Shuen, A. (1997). Dynamic capabilities and strategic management. Strategic Management Journal, 18(7), 509-535.

Vissak, T., Lukason, O., \& Segovia-Vargas, M. J. (2018). Interconnecting exporter types with export growth and decline patterns: evidence from matched mature Estonian and Spanish firms. Review of International Business and Strategy, 28(1), 61-76.

Wagner, J. (2012). Average wage, qualification of the workforce and export performance in German enterprises: evidence from KombiFiD data, Journal of Labour Market Research, 45, 161-170.

Wagner, J. (2014). Credit constraints and exports: evidence for German manufacturing enterprises. Applied Economics, 46(3), 294-302.

Whited, T. M., \& Wu, G. (2006). Financial constraints risk. The Review of Financial Studies, 19(2), 531-559.

Williamson, R., \& Yang, J. (2016). Can financially constrained firms loosen their constraints through acquisitions? SSRN Electronic Journal, DOI: 10.2139/ssrn.2336022.

Witten, I. H. \& Frank, E. (2005). Data Mining: Practical Machine Learning Tools and Techniques, 2nd. Edition, San Francisco. Morgan Kaufmann. 